all eternity. But who put a meaning into them, and what purpose does it serve? If God put it there in the beginning, why did $\mathrm{He}$ waste this value, since it is of no use to man till he puts meaning into it for himself? Why isn't it as high a conception of God to believe that He made it possible for truth to be the final productso far as there can be anything final in human life-of the relations of men to each other? Why isn't the belief that truth is eternally being made as good and pure a belief as its opposite?

And think of the democracy of it! We are not the subjects of any autocratic power in our moral natures, but are the makers of our own moral destiny. It seems to me a most inspiring philosophy to be able to say with William James: "There is no such thing possible as an ethical philosophy dogmatically made up in advance. IVe all help to determine the content of ethical philosophy so far as we contribute to the race's moral life. In other words, there can be no final truth in ethics any more than in physics, until the last man has had his say." (The Will to Beliere, p. 18t.)

Man is the measure and the maker of all things human, and without him is not anything made which hath been, or shall be made. No autocrat dictates to him what his character or ideals shall be. The world of morals is a true democracy.

\title{
THE SOCIETY FOR THE DIFFUSION OF USEFUL KNOWLEDGE.
}

BY JAMES CARLILE.

IN the autumn of the year 1826 Henry Brougham propounded to Natthew Davenport Hill the idea of a society to be formed for the purpose of publishing works of an instructive character at cost price. Davenport Hill sought about for a publisher who would undertake the work under the auspices of the proposed society, and he bethought himself of young Charles Knight, the son of a IVindsor bookseller, who had himself made a small venture in the direction of periodical literature. Hill wrote to Charles Knight to come to town, and took him one evening in November to Brougham's chambers in Lincoln's Inn.

To the end of his very long life Charles Knight retained a vivid impression of that evening's conversation. Brougham was 
then in the height of his power: for some years both with pen and voice he had been doing the work of six capable men; he had taken all knowledge for his province, and he seemed to Charles Knight that evening to be nothing less than an intellectual archangel, as he expounded to the young publisher his idea that sound information in all departments of human thought should be rendered accessible to all classes of the community, even the very poorest.

The moment was really an auspicious one for such an attempt. Though, to the outward eye, England might seem entirely occupied with party politics, yet there was also considerable intellectual stirring. The London University had lately been founded: in all the larger towns literary and scientific societies were growing up; mechanics institutes were spreading in the smaller towns, and there were already the beginnings of cheap reprints in Edinburgh and the northern towns. True there was no system of primary or secondary education except in Scotland, and Brougham had so far failed in his repeated endeavors to bring his adopted country up to the level of the country of his birth. But there were many signs of a genuine thirst for knowledge, and the three men determined to embark on the task of testing the depth and extent of that desire.

Brougham drafted the prospectus of a society whose object was to be the "imparting of useful information to all classes of the community, particularly to such as are unable to avail themselves of experienced teachers or may prefer learning by themselves." To this prospectus he secured the support of the following, all of whom became active members of the Committee: William Allen, Lord Althorp, C. Bell, T. Fowell Buxton, T. Denman, Agar Ellis, Richard Forster, Olinthus Gregory, Isaac L. Goldsmid, Henry Hallam, Capt. Basil Hall, Matthew Davenport Hill, Rowland Hill, George Cornewall Lewis, George Long, J. W. Lubbock, Sir J. Mackintosh, Dean Naltby, John Herman Merivale, James Mill, Lord Nugent, Sir H. Parnell, T. Spring Rice, Lord John Russell, Lord Suffield.

There are few among the above names who are not worthy of rem-mbrance even after the lapse of nearly a century. A more capable committee was never brought together, and when we add that it included a Quaker, a Jew, a bishop (for Maltby became bishop of Durham), and more than one agnostic, it would appear to have been fairly representative, save for the fact that it included no one who could be regarded as an opponent of reform.

The original Prospectus promised a number of elementary treatises explanatory of the fundamental doctrines of every department of human thought. Each "treatise" was to consist of about thirty- 
two octaro pages and to be issued to the public at the price of sixpence. The Committee included in their scheme a series of volumes under each of the following headings: Natural Philosophy (including Mathematics), Intellectual Philosophy, Ethical Philosophy, Political Philosophy, History of Science, History of Nations, and Biographies of Individuals. Brougham led off with a preliminary "Discourse on the Objects, Advantages, and Pleasures of Science." But before the Committee had been in existence six months its work began to assume a more ambitious form, and it was resolved that the Society should aim at publishing a complete "Library of Useful Knowledge," including not merely the elements but the latest developments of every branch of knowledge; and concurrently with this the Committee decided to publish a "Library of Entertaining Knowledge" consisting of volumes, largely illustrated, relating to history, biography, antiquities, travel, and discovery. Brougham led off this series also with a pamphlet to which he gave the title which became a national catchword, "The Pursuit of Knowledge under Difficulties."

The need of a publisher who should devote his whole time to the Society's work became pressing, and, at a meeting of the Committee in July, 1827 (James Mill in the chair), it was resolved that Charles Knight be requested to undertake the superintendence of the Society's publications. Thenceforward Charles Knight devoted himself to the work of the Society to such purpose that to all outward sceming the name "Useful Knowledge Society" was merely a title which appeared on the front page of Charles Knight's publications. This was very far from being the whole truth, for Charles Knight has himself testified to the immense amount of work, voluntary and unpaid work, which was done by the majority of the Committee; but it is certain that the most important part of the Society's publications would never have been undertaken at all if it had not been for Charles Knight's initiative and his incessant personal exertions.

Knight had, before he left Windsor, tried his hand at a little Penny Magazine. He now persuaded the Committee to embark on The Penny Magazine of the Society for the Diffusion of Useful Knowledge. The weekly penny number consisted of eight pages, small folio, double columns. The contents of the number for October 13, 1832, will give a fair idea of the general plan of the magazine:

Tivoli (illustrated).

The Flemish Language.

The Diving Bell (illustrated). 
Fascination of Serpents (illustrated).

Natural Magic.

Two Biographies of the Week.

The Ornithorhyncus.

At the close of the first twelve months, when the fifty-two numbers appeared in volume form, the Society was able to congratulate its subscribers on the success of the magazine. Forty years earlier Edmund Burke had estimated the number of readers in Great Britain at 80,000 . The Society had now shown that a periodical containing no element of sensationalism or excitement, no gossip or abuse, no fiction and no party politics could command a weekly sale of 200,000. The financial profit was not large, for the expense of woodcuts was considerable and the Excise duty of threepence in the lb. on the paper amounted to $£ 70$ a week.

The Society had now reached a point at which it challenged the two indispensable accompaniments of success, imitation and abuse. The "Christian Knowledge Society" devoted a part of its large funds to the publication of the Saturday Magazine, an avowed imitation of the Penny Magazine, and soon afterward the same body superintended the preparation of a series of popular works on general literature and science. The publication of the first few volumes of the "Library of Entertaining Knowledge" was followed immediately by Mr. Murray's announcement of his "Family Library," and the "Library of Useful Knowledge" found an immediate competitor in Lardner's Cabinet Cyclopcedia, a series of separate treatises differing in form from the Society's "Library" but identical in plan.

As to the abuse, it was plentiful. Cobbett in his Register attacked the "Society for the Confusion of Useful Knowledge" and derided its Penny Magazine thus:

"The Penny Magazine has this day a portrait of the American wood-pigson. When I was in America, I once brought down fifteen of them at one shot, and none of them were such fools as the readers of this penny stuff who suppose they are gathering in what is called useful knowledge. If you want useful knowledge read my Register."

This was followed up by much more to the same effect in Cobbett's usual breezy style.

Attacks of a more spiteful nature began in the Nere Monthly Magazine in 1833. The Society's publications were described as "fraudulent pretense," "anti-Christian propaganda," "concealing under the guise of popular instruction a mere bookseller's specula- 
tion bringing in thousands a year to Charles Knight," and so on. The allegation of irreligion was one which weighed seriously with many people with whom it was an article of faith that all instruction should have a direct religious purpose and that scientific teaching of any other description led straight to infidelity.

On June 30, 1832, the Committee announced in a circular to the subscribers that the success of the Penny . Magazine had induced the Committee to undertake the publication of a Penny Cyclopadia, intended to be a moderate-sized book of eight volumes, adapted to the class of readers who had supported the Magazine. It was intended to be a compilation, not a collection of original articles, and Prof. George Long, of London Lniversity, was called in to take the editorship and to assume control of the staff of contributors. Naturally he turned for advice to his colleagues in Gower Street and especially to Alexander Ramsay and Augustus De Morgan. To these three, with Charles Knight, belongs the credit of transforming the Cyclopadia from the modest reference book for the newspaper reader originally designed by the Committee, into a work of the greatest value to scholars and students of that and the next generation. With a sublime disregard for the limitations of size imposed by the Society, the editors had only reached the letters $A n$ when the first volume was finished and the eighth volume found them still in the letter $C$. Ultimately twenty-seven volumes were issued, followed by two more supplomentary volumes.

The Penny Cyclopadia was the magnum opus of the Useful Knowledge Society. It was not completed until the year 1844 , by which time its cost had amounted to $£+2,000$ for literature and illustrations, and $\notin 16,000$ in Excise duties. During all the eleven years occupied in its publication, the monthly parts were never once behindhand for a single day. But after the first year it was found necessary to raise the weekly $1 \mathrm{~d}$. to $2 \mathrm{~d}$., and after three years the price was raised to threepence. The sales during the first year were 75.000 a week: when the price was doubled the sales fell off to 55.000 a week: after two years the number decreased to 44,000 , and before the end of the alphabet had been reached the subscription had fallen to 20,000 a week. The copyright of the work was vested in Charles Knight who some years later reissued it in a revised and altered form under the name The English Cyclopedia. Charles Knight estimated that the two works had involved him in a loss of 430,788, but he had the satisfaction of having published a work which, in the departments of biograplyy, of mathematics, and of certain portions of physical science, is of permanent value, and 
which contains such original and suggestive matter as the contributions of De Morgan and such a masterpiece of exposition as G. B. Airy's article on "Gravitation."

The Society now proceeded to effect two other important reforms. The only existing maps were either incredibly bad or very costly, frequently both. The Society had an entirely fresh series of two hundred maps prepared for publication, together with a number of plans of important cities. When finished they constituted an atlas such as had not hitherto been seen, and yet it was sold at a fraction of the cost of the cheapest of its predecessors. The second new departure was the British Almanac and Companion, which the Society issued annually until its dissolution. This was the first really useful and trustworthy almanac published in Great Britain, and the Companion contained each year some articles of permanent interest and worth.

The Society's income from subscriptions never exceeded $£ 300$ a year, but from the royalties on some of its works it derived considerable sums, all of which it devoted to the publication of works of utility on which no profit could be expected. Such were a set of large astronomical maps. a tabulation of the sickness and mortality experience of Friendly Societies, tables of logarithms and of squares, cubes, etc., and a set of statistics both of Great Britain and of the British Empire.

The Society's last great enterprise was a general biographical dictionary. The scale on which it was planned may be judged from the fact that seven volumes were required to complete the letter $A$. It would thus have rivaled in extent any work of the kind ever execut $=d$ or even contemplated. But the reception of the work was chilling; only 1161 copies of the first volume were sold, and only 789 of the seventh volume, and the loss involved in these volumes exceeded $£ 5,000$.

It was this loss which led to the dissolution of the Society. Lord Campbell, indeed, in his Life of Brougham, attributes the untimely death of the Society to the fact that it published Brougham's volumes on Political Philosophy. But as a matter of fact Brougham's fragment had been published six years earlier. In a dignified address to the public (the composition, largely, of Professor De Morgan) the Committee announced the reasons which led them to advise the dissolution of the Society. The Committee felt that their work had been done. "The fear of the spread of knowledge has now departed"; and they claim, fairly and justly, that "the effect of the Society's labor is proved by the extensive 
adoption of the principles on which they started," and, it may be added, the principles which they unhesitatingly pursued to the end. "Its efforts have had a remarkable success in bringing before large numbers an amount of accurate knowledge which was formerly the property of a few only. The industrious student, if he required books of a high character, was obliged to content himself with those of a past age, which had gradually descended within his means as to price. If he can now commence his labors with the advantage of more modern assistance, he has to thank in great measure those who discovered for him that books of the more learned character might be successfully published on the principles of cheapness which had been so often applicd in other branches of trade. The numbers of editions of the best writers on all subjects which have appeared at almost artisan's prices within the last six years, and the amount of books now obtainable by persons of very small means, may without arrogance be attributed to the example of the 'Society for the Diffusion of Useful Knowledge'" (18+6).

The following is believed to be a complete list of the Society's publications :

1. "The Library of Useful Knowledge," comprising three hundred and sixty volumes or pamphlets.

2. "The Farmer's Series," being a library of pamphlets on agriculture.

3. "The Library of Entertaining Knowledge."

4. The Journal of Education, a quarterly continued during the Society's existence.

5. The Penny Magazine-nine volumes.

6. The Penny Cyclopadia-twenty-nine volumes.

7. The Society's Atlas of two hundred maps.

8. The Star Atlas.

9. The Gallery of Portraits with biographies, seven volumes.

10. The British Almanac and Companion, continued annually.

11. The Working Man's Companion.

12. The "Library for the Young."

13. The Statistics of Great Britain and of the Colonies.

14. A Treatise on Friendly Societies.

15. A Treatise on Annuities.

16. A Manual for Mechanics Institutes.

17. A series of treatises on governments (a design of Brougham's left unfinished).

18. Several sets of mathematical tables.

19. The Pictorial Bible.

20. The Biograplical Dictionary (not completed).

There are also other works projected by the Society, some of which were afterward completed and published by Charles Knight. 